\title{
HASIL BELAJAR MELALUI PENERAPAN MODEL PEMBELAJARAN KOOPERATIF TYPE STUDENT TEAMS ACHIEVEMENT DIVISION (STAD) KONSEP SISTEM GERAK PADA MANUSIA DI KELAS VIII E SMP NEGERI 4 BANJARMASIN
}

\author{
Irawati $^{1} \&$ Rokiah $^{2}$
}

1. SMP Negeri 4 Banjarmasin irawati_smp4@yahoo.com (0181348896735)

2. SMP Negeri 4 Banjarmasin yayah_rokiah@yahoo.co.id (085248344386)

\begin{abstract}
ABSTRAK
Telah dilakukan penelitian tindakan kelas Penerapan Model Pembelajaran Kooperatif Type Student Teams Achievent Division (STAD) pada konsep Sistem Gerak Pada Manusia di kelas V111 E SMP Negeri 4 Banjarmasin dengan tujuan ingin mengetahui sejauh mana Penerapan Model Pembelajaran Kooperatif Type Student Teams Achievent Division (STAD) dapat meningkatkan hasil belajar, aktivitas siswa, keterlaksanaan guru dalam pembelajaran serta respon siswa terhadap pembelajaran IPA siswa SMP Negeri 4 Banjarmasin.Penelitian ini dilaksanakan dengan metode rancangan tindakan kelas, subyek penelitian adalah siswa kelas V111 E SMP Negeri 4 Banjarmasin yang berjumlah 32 yang terdiri dari 16 anak laki-laki dan 16 anak perempuan, yang dibagi 8 kelompok. Penelitian ini dilakukan selama 3 bulan dan data dianalisis secara deskriptif. Hasil penelitian menunjukkan bahwa pembelajaran dengan menggunakan Penerapan Model Pembelajaran Kooperatif Tipe STAD dapat meningkatkan hasil belajar siswa konsep Sistem Gerak Pada Manusia di kelas V111 E di SMP Negeri 4 Banjarmasin yang sangat signifikan terbukti dari fakta yaitu nilai rata-rata secara klasikal pada pre test $21,87 \%$ pada siklus 1 dan pos test $68,75 \%$ sedangkan pada siklus 2 pre test $31,25 \%$ dan pos test $90,63 \%$. Untuk keaktifan siswa sudah baik karena dari 9 parameter terdapat 5 parameter lebih dari 10\%, keterlaksanaan guru dalam pembelajaran pada siklus $13,76 \%$ dan pada siklus 2 mengalami peningkatan menjadi 3,94\% dan respon siswa baik pada siklus 1 dan sikls 2 sudah baik. Dengan demikian dengan Penerapan model pembelajaran Kooperatif Tipe STAD membantu meningkatkan hasil belajar dan memudahkan siswa untuk memahami konsep Sistem Gerak Pada Manusia.

Kata kunci : Konsep Sistem Gerak Pada Manusia, Penerapan Model Pembelajaran Kooperatif Type Student Teams Achievent Division (STAD), Hasil belajar siswa.
\end{abstract}

\section{PENDAHULUAN}

Berkaitan dengan mata pelajaran biologi yang tergabung dalam rumpun IPA, KTSP menyatakan bahwa "Pendidikan IPA menekankan pada pemberian pengalaman lansung untuk mengembangkan kompetensi agar siswa mampu menjelajahi dan memahami alam sekitar secara ilmiah. Pendidikan IPA diarahkan untuk mencari tahu dan berbuat sehingga dapat membantu siswa untuk memperoleh pemahaman yang mendalam tentang alam sekitar" (Depdiknas, 2006).

Bila memperhatikan tujuan pembelajaran IPA di SMP tersebut, maka dapat diartikan bahwa pembelajaran IPA harus dilaksanakan dengan pertimbangan-pertimbangan (1) berorientasi pada pendekatan keterampilan proses; (2) keterlibatan siswa secara aktif dalam pembelajaran; (3) menemukan sendiri pengetahuannya berdasarkan pengamatannya. 
Berdasarkan perolehan rata-rata UN IPA yakni pada tahun $2017=7,18 \mathrm{di}$ SMP Negeri 4 Banjarmasin sudah cukup baik namun kenyataan di lapangan masih banyak pengajaran IPA terbatas pada produk, konsep, dan teori,serta masih dilaksanakan secara tradisional sementara segi psikomotor dan afektif penekanan pada proses pembelajaran belum dilaksanakan secara maksimal. Hal ini menyebabkan siswa kurang memahami konsep IPA yang diperoleh di kelas untuk memecahkan masalah kehidupan sehari-hari. Untuk menghadapi arus globalisasi di bidang pendidikan perlu adanya upaya peningkatan kualitas pembelajaran yaitu penyusunan skenario berbagai kegiatan pembelajaran di kelas.

Meningkatkan kualitas pembelajaran diperlukan model pembelajaran. Di mana model pembelajaran merupakan strategi yang digunakan oleh guru untuk meningkatkan motivasi belajar, sikap belajar dikalangan siswa, memiliki keterampilan sosial dan pencapaian hasil pembelajaran yang optimal (Isjoni, 2010). Untuk meningkatkan hasil belajar siswa serta memberi kesempatan secara aktif membangun pengetahuannya sendiri. Pembelajaran yang demikian itu sangat penting diwujudkan di kelas, karena pembelajaran merupakan mental aktif, bukan menerima pengajaran dari guru secara pasif. Untuk proses ini guru berperan sebagai direktur belajar artinya guru senantiasa berusaha untuk menimbulkan, memelihara, dan meningkatkan motivasi siswa untuk belajar sekaligus sebagai pembimbing dalam proses belajar mengajar, namun siswa tetap merupakan kunci pembelajaran (Slameto, 2010).

Model pembelajaran kooperatif dikembangkan untuk mencapai tiga tujuan instruksional penting yaitu: (1) Hasil belajar akedemik, (2) penerimaan terhadap perbedaan individu dan (3) pengembangan keterampilan sosial (Isjoni, 2010). Demikian pula halnya lingkungan belajar kooperatif bercirikan proses demokrasi dan dapat diharapkan suasana terbuka dengan kebiasaan kerja sama, terutama dalam memecahkan kesulitan (Isjoni, 2010). Selain daripada itu, tujuan penting dari pembelajaran kooperatif ialah mengajarkan siswa keterampilan kerja sama dan berorganisasi. Fakta lain menunjukkan bahwa pembelajaran biologi di SMP kurang dalam melaksanakan belajar kelompok dan diskusi kelas. Hal ini menggambarkan pembelajaran IPA masih

bersifat pasif (Rahayu dalam Suryati, 1996). Model pembelajaran ini, memungkinkan siswa dapat meraih keberhasilan dalam belajar, melatih memiliki keterampilan berpikir dan keterampilan sosial, dan mengembangkan pengetahuan, kemampuan,dan keterampilan secara penuh dalam suasana belajar yang terbuka dan demokrasi. Siswa bukan lagi sebagai obyek pembelajaran, namun bisa juga sebagai tutor bagi teman sebayanya (Stahl dalam Isjoni, 2010). Menurut Isjoni (2010), pada model pembelajaran kooperatif siswa diberi kesempatan untuk berkomunikasi dan berinteraksi sosial dengan temannya untuk mencapai tujuan pembelajaran, sementara guru sebagai motivator dan fasilitator aktivitas siswa. Pembentukan kelompok kooperatif memberikan kesempatan pada siswa secara aktif dengan pengetahuan dibangun sendiri dan bertanggung jawab atas hasil pembelajarannya.

Perkembangan ilmu pengetahuan dan teknologi semakin mendorong upaya-upaya pembaharuan dalam pemanfaatan hasil-hasil teknologi dalam proses belajar. Penelitian model pembelajaran kooperatif tipe STAD dilakukan Siti (2008) pada konsep penyusunan makhluk hidup dengan lingkungannya melalui model pembelajaran kooperatif tipe STAD menunjukkan ada pengaruh bahwa 
siswa telah mencapai ketuntasan klasikal pada tes akhir. Pada siklus 1 pertemuan 1 ketuntasan klasikal sebesar 85,71\%, siklus 1 pertemuan 2 sebesar 92,86\%, pada siklus 2 pertemuan 1 sebesar $92,86 \%$, pada pertemuan 2 sebesar 92,86\%. Hasil dari LKS tergolong dalam kategori baik yang mana pada pertemuan 1 dan siklus 1 sebesar $86,19 \%$, pertemuan 2 siklus 2 sebesar 80,91\% dan pertemuan 2 siklus 2 sebesar $95,71 \%$ pembelajaran dengan menggunakan metode pembelajaran kooperatif tipe STAD dapat dijadikan salah satu pilihan pembelajaran IPA di SD. Hasil penelitian Khairunnisa (2007) tentang pemahaman konsep Daur Hidup dengan siswa SDN Batu Piring Paringin Balangan dengan menggunakan pendekatan kooperatif tipe STAD melalui media medical wheel mendapat respon yang positif dan siswa menjadi aktif serta meningkatkan hasil belajar.

Berdasarkan uraian di atas, maka pembelajaran yang berorientasi pada kerja sama antar siswa guna meningkatkan kemampuan akedemik, dan keterampilan sosial perlu bagi siswa sebagai bekal bermasyarakat/berorganisasi bila dewasa kelak. Mengacu pada uraian tersebut, maka judul penelitian ini adalah Hasil Belajar melalui Penerapan Model Pembelajaran Kooperatif type Student Teams Achievement Divisions (STAD) dengan Konsep Sistem Gerak Manusia di SMP Negeri 4 Banjarmasin.

\section{A. Rancangan Penelitian}

\section{METODE PENELITIAN}

Penelitian tentang penggunaan model pembelajaran langsung dalam pembelajaran IPA ini merupakan Penelitian Tindakan Kelas (PTK). Penelitian ini merupakan kegiatan yang dilakukan oleh guru yang bertujuan untuk memperbaiki berbagai persoalan nyata dan praktis dalam peningkatan mutu pembelajaran di kelas yang dialami langsung dalam interaksi antara guru dengan siswa yang sedang belajar (Arikunto, dkk, 2006).

Tujuan dari PTK adalah untuk meningkatkan kemampuan, kemantapan rasional dari tindakan-tindakan mereka dalam melaksanakan tugas, memperdalam pemahaman tentang tindakan-tindakan yang dilakukannya dan memperbaiki kondisi di mana praktik-praktik pembelajaran dilakukan (Arikunto., dkk, 2006).

Penelitian ini direncanakan 2 siklus dengan 2 kali pertemuan, siklus I terdiri atas 1 kali pertemuan dan pada siklus II terdiri atas 1 kali pertemuan. Siklus I pertemuan 1 Konsep sistem rangka pada manusia Siklus 2 pertemuan 1 mempelajari tentang macam-macam otot,gangguan/kelainan, dan upaya mengatasi pada sistem gerak manusia. Pada pelaksanaan pembelajaran, peneliti berkolaborasi dengan 2 orang guru Kelas V1II SMP Negeri 4 Banjarmasin. Tugas masing-masing peneliti diatur sedemikian rupa sehingga memperlihatkan kesatuan tindakan antara peneliti dan kolaboran. Tugas-tugas tersebut ada yang bertindak sebagai pengamat.

\section{B. Pelaksanaan Penelitian Tindakan pada Siklus 1}

a. Refleksi Awal

Berdasarkan hasil belajar mata pelajaran IPA di SMPN 4 Banjarmasin, dapat diuraikan refleksi awal sebagai berikut:

- Konsep sistem gerak pada manusia di SMP Negeri 4 Banjarmasin dtingkat ketuntasan belajar siswa pada konsep ini hanya mencapai $60 \%$ dan $40 \%$ siswa nilainya masih di bawah standar ketuntasan padahal kriteria ketuntasan yang ditetapkan adalah sebesar 70 .

Pertemuan I 


\section{( 1 ) Tahap Perencanaan}

Pada pertemuan pertama untuk melaksanakan tujuan pembelajaran produk 1 .

Tahap-tahap dalam perencanaan ini meliputi:

(a) Membuat silabus dan penilaian untuk konsep sistem gerak pada manusia. Merancang Rencana Pelaksanaan Pembelajaran (RPP) menggunakan model pembelajaran kooperatif Type Student Teams Achievement Divisions (STAD)

(b) Menyusun materi pembelajaran dari beberapa buku sumber.

(c) Menyusun LKS tentang konsep rangka tubuh manusia dan persendian. LKS diberikan selama proses pembelajaran di dalam kelas.

(d) Menyusun soal-soal tes (pre tes dan post tes), tentang konsep rangka tubuh manusia dan persendian serta format pengisian angket respon siswa. selama proses pembelajaran.

2. Melaksanakan Tindakan

Kegiatan yang dilakukan pada tahap ini adalah:

(a) Melaksanakan pre test kepada siswa tentang energi dan usaha.

(b) Mengelompokkan siswa dalam kelompok kecil, yang terdiri dari 3-5 orang siswa untuk melaksanakan model pembelajaran kooperatif Tipe STAD materi konsep rangka tubuh manusia dan persendian.

(c) Membagikan LKS 1 kepada masing-masing kelompok yang sudah terbentuk.

(d) Meminta setiap kelompok melakukan pengamatan melalui gambar sesuai dengan LKS 1

(e) Membimbing siswa dalam kelompok melakukan pengamatan melalui gambar.

(f) Menyimpulkan pelajaran bersama-sama dengan siswa.

(g) Melaksanakan pos test untuk mengetahui sejauh mana pemahaman siswa terhadap materi yang dipelajari.

(h) Memberikan penghargaan atau pengakuan pada siswa atau kelompok terbaik.

( 3 ) Observasi dan Evaluasi Tindakan

Kegiatan pada tahap ini adalah sebagai berikut:

(a) Respon siswa selama proses pembelajaran dan pengelolaan pembelajaran guru menggunakan lembar observasi (Allyn \& Bacon dalam Nur, 2005) .

(b) Penguasaan materi di lihat dari evaluasi terhadap hasil belajar siswa yang diperoleh dari hasil pre tes dan post tes dengan menggunakan ketuntasan klasikal dan ketuntasan individual.

(c) Evaluasi terhadap hasil selama proses pembelajaran diperoleh dari hasil LKS meliputi pengetahuan dan keterampilan proses yang ditetapkan secara kategorikal (Arikunto, 1998).

Seluruh data hasil penelitian dicatat atau direkam untuk dijadikan bahan pertimbangan dalam melakukan refleksi tahap kedua.

( 4 ) Refleksi

Pada tahap ini dilakukan evaluasi terhadap proses pembelajaran pada siklus 1 dan menjadi pertimbangan untuk memasuki siklus 2. Pertimbangan yang digunakan bilamana komponen dibawah ini belum terpenuhi.

(a) Ketuntasan belajar siswa secara individu tercapai bila siswa tersebut mendapat nilai $\geq 70$ dan ketuntasan klasikal jika $\geq 85 \%$ dari seluruh siswa mencapai ketuntasan individual. Ketuntasan belajar siswa dilihat dari nilai post test setiap pertemuan.

(b) Kategori hasil selama proses pembelajaran adalah baik, berdasarkan kategori Arikunto (1998). 
(c) Aktivitas siswa, respon siswa dan keterlaksanaan pembelajaran guru, berdasarkan parameter respon siswa dan keterlaksanaan pembelajaran guru menggunakan lembar observasi dan angket M.Nur (M.Nur, 2005).

\section{Pelaksanaan Penelitian Tindakan pada Siklus 2}

Pertemuan 2

( 1 ) Tahap Perencanaan

Pada pertemuan kedua untuk melaksanakan tujuan pembelajaran.Tahap-tahap dalam perencanaan ini meliputi:

(a) Merancang rencana pelaksanaan pembelajaran (RPP) menggunakan Model Pembelajaran Kooperatif Tipe STAD.

(b) Menyiapkan LKS 2 tentang macam-macam otot dan kelainan/gangguan sistem gerak, LKS diberikan selama proses pembelajaran.

(c) Menyusun soal pre test dan pos test, dan kisi-kisi soal untuk konsep macammacam otot dan kelainan/gangguan sistem gerak, respon siswa dan keterlaksanaan guru selama proses pembelajaran melalui pengisian angket pada akhir pembelajaran.

( 2 ) Melaksanakan Tindakan

Kegiatan yang dilakukan pada tahap ini adalah:

(a) Melaksanakan pre test kepada siswa tentang konsep energi dan usaha

(b) Menjelaskan pembelajaran tentang konsep sistem gerak pada manusia dengan contohnya.

(c) Mengelompokkan siswa dalam kelompok kecil, yang terdiri dari 3-5 orang siswa untuk melaksanakan pembelajaran dengan menggunakan model pembelajaran kooperatif Tipe STAD.

(d) Membagikan LKS 2 untuk nantinya secara berkelompok. dikerjakan.

(e) Membimbing siswa dalam kelompok mengisi LKS.

(f) Mempresentasikan hasil tulisan semua kelompok secara bergantian.

(g) Menyimpulkan pelajaran bersama-sama dengan siswa.

(h) Melaksanakan pos test untuk mengetahui sejauh mana pemahaman siswa terhadap materi yang dipelajari.

(i) Memberikan penghargaan atau pengakuan pada siswa atau kelompok terbaik.

( 3 ) Observasi dan Evaluasi Tindakan

Kegiatan pada tahap ini adalah sebagai berikut:

(a) Respon siswa selama proses pembelajaran dan keterlaksanaan pembelajaran guru menggunakan lembar observasi (Allyn \& Bacon dalam Muhammad Nur, 2005) .

(b) Penguasaan materi di lihat dari evaluasi terhadap hasil belajar siswa yang diperoleh dari hasil pre tes dan post tes dengan menggunakan ketuntasan klasikal dan ketuntasan nilai.

(c) Evaluasi terhadap hasil selama proses pembelajaran diperoleh dari hasil LKS meliputi pengetahuan yang ditetapkan secara kategorikal (Arikunto, 1998).

( 4 ) Refleksi Akhir

Pada tahap ini seluruh data hasil penelitian dicatat atau direkam untuk dijadikan bahan pertimbangan dalam menjawab tujuan penelitian yang telah dirumuskan.

\section{Setting Penelitian}

1.Waktu dan Tempat Penelitian 
Penelitian ini direncanakan akan dilaksanakan dari bulan September hingga Nopember 2017. Penelitian dilakukan di SMP Negeri 4 Banjarmasin yang beralamat Jln. Teluk Tiram Darat No. 1 Kecamatan Banjarmasin Barat Kelurahan Teluk Tiram. Kalimantan Selatan, pada semester Ganjil Tahun Pelajaran 2017/2018.

2. Subjek Penelitian

Subyek dalam penelitian ini adalah siswa kelas VIII E SMP Negeri 4 Banjarmasin yang berjumlah 32 orang, yaitu 16 orang laki-laki dan 16 orang perempuan.

\section{E. Instrumen Penelitian} sebagai berikut:

Perangkat instrumen yang digunakan dalam penelitian ini adalah

1. Instrumen Tes

Instrumen tes kognitif dilakukan untuk mengukur pemahaman konsep siswa menggunakan bentuk soal objektif ( pilihan ganda ) dengan 4 pilihan jawaban yang terdiri dri 1 pilihan dan 3 jawaban pengecoh. Tehnik penskoran untuk instrumen tes obyektif ditentukan dengan cara memberi skor 1 untuk jawaban yang benar dan skor 0 untuk jawaban yang salah. Peneliti merancang sebanyak 20 butir soal untuk tes objektif multiple choice.

2. Instrumen non tes

Instrumen non tes berupa aktivitas siswa ,dilakukan untuk mengetahui apa saja yang dilakukan siswa selama proses belajar yang sudah disediakan instrumen penilaan terdiri dari 10 buir aktivitas siswa selama mengikuti pembelajaran dan kuesioner respon belajar untuk memperoleh data respon siswa. Respon siswa dilakukan untuk mengetahui bagaimana tanggapan dan ketetarikan siswa terhadap pembelajaran menggunakan bentuk angket dengan pilihan jawaban senang, tidak senang, baru, tidak baru, ya dan tidak. Ada 16 butir pertanyaan dan untuk keterlaksanaan pembelajaran guru untuk mengetahui bagaimana guru menyampaikan materi pembelajaran diadaptasi dari M. Nur, 2005.

3. Validitas Instrumen

Instrumen penelitian memenuhi syarat sebagai alat pengumpul data apabila instrumen penelitian tersebut valid dan reliabel (Arikunto, 1998). Uji validitas instrument bertujuan untuk mengetahui tingkat kesesuaian instrument penelitian dengan tujuan dan isi materi pelajaran. Soal-soal tes dilakukan uji validitas dan reliabilitas dengan memberikan kepada siswa SMPN 4 Kelas V111 B. Uji validitas RPP dan LKS dilakukan oleh guru mata pelajaran IPA, sedangkan uji soal dengan menggunakan Tabel FAN.

\section{F. Teknik Pengumpulan Data}

1. Tes, adalah data kuantitatif diperoleh dari tes hasil belajar (pretest dan postest)

2. Observasi adalah data kualitatif hasil observasi oleh obsever terhadap keterlaksanan pembelajaran guru dann aktivitas siswa.

3. Angket adalah data kualitatif diperoleh dari pengisian angket respon siswa terhadap kegiatan pembelajaran.

\section{G. Teknik Analisis Data}


Teknik analisis data dilaksanakan sesuai dengan jenis data yang telah dikumpulkan sebagai berikut:

1) Analisis data hasil penelitian yang tergolong data kuantitatif yang tertuju pada hasil belajar produk yang dilakukan secara deskriptif. Data ini berasal dari tes hasil belajar selama proses pembelajaran. Data tes hasil belajar diolah dengan menghitung ketuntasan klasikal dan ketuntasan individual dengan rumus:

Ketuntasan Nilai $=$ Jumlah skor $\times 100$

Jumlah skor maksimal

Ketuntasan klasikal $=$ Jumlah siswa yang tuntas belajar $\times 100 \%$ Jumlah seluruh siswa

Keterangan:

Ketuntasan individual: Jika siswa mencapai ketuntasan skor $\geq 70$

Ketuntasan klasikal: Jika $\geq 85 \%$ dari seluruh siswa mencapai ketuntasan skor $\geq 70$

Data hasil selama proses pembelajaran ditafsirkan ke dalam kalimat kualitatif yakni baik (76-100\%), cukup baik (56-75\%), kurang (40-55\%), dan buruk $(<40 \%)$ (Arikunto, 1998).

2) Analisis data tentang hasil penelitian yang tergolong data kualitatif dilakukan secara deskriptif tentang pengelolaan pembelajaran yang dilakukan guru dalam pembelajaran.

3) Analisis data tentang respon siswa dilakukan dengan menghitung persentase jawaban setiap butir soal dari angket respon siswa terhadap kegiatan pembelajaran, kemudian dianalisis secara deskriptif.

\section{HASIL DAN PEMBAHASAN}

Penelitian tentang Meningkatkan Hasil Belajar Melalui Penerapan Model Pembelajaran Kooperatif Type Student Teams Achievement Divisions (STAD) di Kelas VIII E SMP Negeri 4 Banjarmasin, telah memperoleh sejumlah data kualitatif berupa data hasil belajar yang diambil dari pre test dan post test. Sedangkan data kualitatif berupa data hasil angket terhadap aktivitas, keterlaksanaan guru dalam pembelajaran dan respon siswa selama proses pembelajaran

\section{A. Hasil}

\section{Hasil belajar pada pembelajaran siklus 1}

Hasil belajar produk meliputi hasil pre test dan post test. Pre test diberikan di awal pembelajaran dan post test diberikan diakhir pembelajaran. Hasil pre test dan post test siklus 1, ringkasannya disajikan pada Tabel 1.

Tabel 1. Ringkasan Data Ketuntasan Individual dan Klasikal yang diperoleh dari Hasil Pre Test dan Post Test Siklus 1

\begin{tabular}{|c|c|c|c|c|c|}
\hline Sumber & \multirow{2}{*}{$\begin{array}{c}\text { Skor } \\
\text { Data }\end{array}$} & \multicolumn{2}{|c|}{ Hasil Belajar } & & Tuntas \\
\cline { 3 - 4 } & Maksimum & Tuntas (org) & Tidak Tuntas (org) & Jumlah & Klasikal \\
\hline Pre test & 100 & 7 & 25 & 32 & $21,87 \%$ \\
Post Test & 100 & 22 & 10 & 32 & $68,75 \%$ \\
\hline
\end{tabular}

Pada Tabel 1 persentase siswa yang tuntas pada pre test hanya sebesar $21,87 \%$. Hal ini menunjukkan kemampuan awal siswa ternyata masih rendah dan belum mencapai ketuntasan klasikal yang telah ditentukan. Berdasarkan hal inilah maka dilaksanakan proses pembelajaran tentang energi dan usaha melalui model 
pembelajaran Kooperatif Type Student Teams Achievement Divisions (STAD) pada siklus 1.

Pada post test, persentase siswa yang tuntas sebesar 68,75\%. Hal ini menunjukkan bahwa ketuntasan klasikal masih belum mencapai batas yang ditetapkan yaitu sebesar $\geq 85 \%$. Peningkatan hasil belajar dari pre test ke post test sebesar 46,88\%. Hal ini berarti penggunaan model pembelajaran Kooperatif Type Student Teams Achievement Divisions (STAD) dapat meningkatkan hasil belajar siswa pada siklus 1 .

\section{Aktivitas Siswa}

Aktivitas siswa pembelajaran siklus 1 ringkasannya seperti pada Tabel 2 . Pada Tabel 2, parameter yang menunjukkan keaktifan siswa tertinggi dalam kategori $\geq 10 \%$ tinggi (baik) yaitu pada parameter $1,2,3,5,7$ dan 8 , dengan aktivitas memperhatikan penjelasan guru atau siswa lain $(15,8 \%)$, membaca LKS atau buku-buku yang relevan $(11,3 \%)$, melakukan pengamatan/percobaan $(13,3 \%)$, berdiskusi antar siswa/ kelompok/ guru (13,3\%), bertanya kepada siswa lain atau guru $(10,8 \%)$ dan menyusun/menyajikan hasil penyelidikan (14,5\%)Sedangkan paramete 4, 6, dan 9, menulis hal yang relevan dengan KBM (7,5\%), merefleksikan dan mengevaluasi informasi hasil penyelidikan $(7,55)$, membuat/menulis rangkuman pelajaran (7\%) menunjukan aktivitas siswa dalam kategori $<10 \%$ rendah (buruk).

Tabel 2. Aktivitas Siswa dalam Pembelajaran pada Siklus 1

Kategori: Aktivitas Siswa $<10 \%$ rendah (buruk), $\geq 10 \%$ tinggi (baik)

\begin{tabular}{|l|l|l|l|l|l|l|l|l|l|l|l|}
\hline Responden & & \multicolumn{7}{|c|}{ Parameter Yang Dinilai } & Jumlah \\
\cline { 2 - 13 } & & 1 & 2 & 3 & 4 & 5 & 6 & 7 & 8 & 9 & \\
\hline \multirow{2}{*}{ Eko .K.S } & $\mathrm{F}$ & 6 & 5 & 4 & 3 & 6 & 3 & 4 & 6 & 3 & 40 \\
\cline { 2 - 13 } & $\%$ & 15 & 12,5 & 10 & 7,5 & 15 & 7,5 & 10 & 15 & 7,5 & 100 \\
\hline \multirow{2}{*}{ M..Fadil. S } & $\mathrm{F}$ & 6 & 4 & 6 & 3 & 6 & 3 & 4 & 5 & 3 & 40 \\
\cline { 2 - 13 } & $\%$ & 15 & 12,5 & 10 & 7,5 & 15 & 7,5 & 10 & 12,5 & 7,5 & 100 \\
\hline \multirow{2}{*}{ Nur. M } & $\mathrm{F}$ & 5 & 6 & 5 & 3 & 5 & 3 & 5 & 6 & 2 & 40 \\
\cline { 2 - 13 } & $\%$ & 12,5 & 15 & 12,5 & 7,5 & 12,5 & 7,5 & 12,5 & 15 & 5 & 100 \\
\hline \multirow{3}{*}{ Nurul. A } & $\mathrm{F}$ & 8 & 3 & 6 & 3 & 4 & 3 & 4 & 6 & 3 & 40 \\
\cline { 2 - 12 } & $\%$ & 20 & 7,5 & 15 & 7,5 & 10 & 7,5 & 10 & 15 & 7,5 & 100 \\
\cline { 2 - 11 } & $\%$ & 15,8 & 11,3 & 13,3 & 7,5 & 13,3 & 7,5 & 10,8 & 14,5 & 7 & 100 \\
\hline
\end{tabular}

Keterangan parameter:

1. Memperhatikan penjelasan guru atau siswa lain.

2. Membaca LKS atau buku-buku yang relevan.

3. Melakukan pengamatan/percobaan

4. Menulis hal-hal yang releven dengan KBM.

5. Berdiskusi antar siswa / kelompok/ guru

6. Melakukan analisis dan mengevaluasi informasi dari hasil penyelidikan.

7. Bertanya kepada siswa lain atau kepada guru.

8. menyusun/menyajikan hasil penyelidikan.

9. Membuat/ menulis rangkuman pelajaran.

Pembelajaran dikatakan baik apabila siswa dapat ikut serta secara aktif dalam pembelajaran (aktivitas siswa tinggi). Aktivitas siswa dikatakan baik apabila nilai kategori aktivitas siswa $\geq 10$ (tinggi) dan dikatakan buruk jika $<10$ 
(rendah). Jumlah siswa yang diamati sebanyak 4 orang siswa dalam 1 kelompok, jika terdapat 2 orang siswa atau lebih yang memiliki tingkat keaktifan $\geq 10 \%$ maka dapat dikatakan bahwa keaktifan siswa pada parameter yang diamati tersebut tinggi. Selain itu apabila pada 9 kategori parameter aktivitas siswa yang diamati terdapat lebih dari atau sama dengan 6 parameter yang nilainya tinggi maka dapat dikatakan bahwa aktivitas siswa pada pembelajaran yang berlangsung baik (siswa aktif).

Pada kegiatan pembelajaran siklus 1 ini aktivitas siswa dapat dikatakan tinggi (baik) karena terdapat 6 parameter dari 9 parameter yang diamati memiliki nilai $\geq 10 \%$. Selain melihat aktivitas yang dilakukan oleh siswa selama proses pembelajaran, perlu juga memperhatikan keterlaksanaan guru dalam pembelajaran.

3. Keterlaksanaan guru dalam pembelajaran pada siklus 1

Tabel 3 Ringkasan Data Keterlaksanan Guru dalam Pembelajaran pada Siklus 1

\begin{tabular}{|l|c|}
\hline \multicolumn{1}{|c|}{ Tahapan } & Siklus 1 \\
\cline { 2 - 2 } & Pertemuan 1 \\
\hline A. Tahapan 1 Kegiatan Awal & 3,78 \\
\hline B. Tahapan 2 Kegiatan Inti & 3,50 \\
\hline C. Tahapan 3 Kegiatan Akhir & 4,00 \\
\hline Rata - Rata & 3,76 \\
\hline Kategori & Baik \\
\hline
\end{tabular}

Keterangan 1 = Kurang baik, $2=$ Cukup baik, 3 = Baik, $4=$ Sangat baik

Berdasarkan Tabel 3 untuk keterlaksanaan pembelajaran yang dilakukan guru pada siklus 1 pertemuan 1 untuk tahapan kegiatan awal, tahapan kegiatan inti dan penutup sudah termasuk dalam kategori baik.

4. Respon siswa terhadap pembelajaran dengan Model Kooperatif Type Student Teams Achievement Divisions ( STAD) pada Siklus 1

Data hasil respon siswa setelah selesai proses belajar mengajar pada pembelajaran siklus 1 ringkasannya seperti pada Tabel 4.

Tabel 4 Respon Siswa terhadap Pembelajaran dengan Model Kooperatif Type Type Student Teams Achievement Divisions ( STAD) siklus 1

\begin{tabular}{|c|c|c|c|}
\hline & Uraian & Senang & Tidak Senang \\
\hline \multirow{7}{*}{\multicolumn{2}{|c|}{$\begin{array}{l}\text { a. Bagaimana pendapatmu terhadap komponen } \\
\text { 1.Topik IPA yang dipelajari } \\
\text { 2.LKS } \\
\text { 3.Buku Siswa } \\
\text { 4.Suasana kelas } \\
\text { 5.Penampilan Guru } \\
\text { 6.Strategi Belajar yang dilatihkan guru (ceramah, } \\
\text { diskusi, pengamatan dan tanya jawab) }\end{array}$}} & & \\
\hline & & $93,75 \%$ & $6,25 \%$ \\
\hline & & $96,87 \%$ & $3,13 \%$ \\
\hline & & $93,75 \%$ & $6,25 \%$ \\
\hline & & $75 \%$ & $25 \%$ \\
\hline & & $90,63 \%$ & $6,25 \%$ \\
\hline & & $87,5 \%$ & $12,5 \%$ \\
\hline \multirow{3}{*}{\multicolumn{2}{|c|}{$\begin{array}{l}11 \text { Apakah kamu berminat untuk mengikuti Kegiatan } \\
\text { Belajar Mengajar berikutnya Seperti Yang telah } \\
\text { kamu ikuti. }\end{array}$}} & $\mathrm{Ya}$ & Tidak \\
\hline & & $90,63 \%$ & $9,37 \%$ \\
\hline & & Ya & Tidak \\
\hline
\end{tabular}


111. Berikan komentarmu terhadap buku siswa Mengenai:

a. Bahasanya mudah dimengerti

b. Penampilan buku menarik

c. Isi buku menarik

Berdasarkan Tabel 4 Pembelajaran siklus 1 menunjukkan bahwa siswa menyatakan terhadap komponen kegiatan belajar mengajar senang 89,58\% dan tidak senang 9,89\%. Berminat mengikuti KBM berikutnya menyatakan ya 90,63\% dan tidak $89,37 \%$, dan memberi komentar terhadap buku siswa ya $92,70 \%$ dan tidak $7,29 \%$. Selain melihat respon yang dilakukan oleh siswa selama proses pembelajaran, perlu juga memperhatikan keterlaksanaan guru dalam pembelajaran yang dilakukan oleh guru.

Evaluasi terhadap proses pembelajaran pada siklus 1 dapat diuraikan sebagai berikut:

1. Kategori hasil belajar selama proses pembelajaran yang meliputi pengetahuan tergolong baik.

2. Siswa telah mencapai ketuntasan klasikal sebesar $52,78 \%$, ketuntasan ini belum melewati batas ketuntasan klasikal yang ditetapkan sebesar $\geq 85 \%$.

3. Aktivitas siswa sudah dapat dikatakan baik karena ada 6 parameter dari 9 parameter keaktifan siswa yang menunjukkan keaktifan siswa yang sudah baik (kategori aktivitas siswa $\geq 10 \%$ ).

4. Respon siswa sudah dikatakan baik karena dari 10 pertanyaan yang menunjukkan senang 90,63\%. Dan yang tidak senang 9,38\%.

Berdasarkan evaluasi proses pembelajaran siklus 1 (khususnya data kualitatif keterlaksanan guru dalam pembelajaran ) dan masih ada materi pada konsep persendian belum selesai diajarkan, maka dapat disimpulkan bahwa penggunaan Model Pembelajaran Kooperatif Type Student Teams Achievement Divisions (STAD ) ini belum mencapai indikator keberhasilan yang ditetapkan, oleh karena itu dilaksanakan pembelajaran pada siklus 2.

\section{Hasil belajar siswa pada pembelajaran siklus 2}

Pada siklus 2 sama halnya dengan siklus 1 yaitu hasil belajar produk berupa pre test yang diberikan di awal pembelajaran dan hasil post test yang diberikan di akhir pembelajaran. Adapun hasil pre test dan post test pada siklus 2 ringkasannya disajikan pada Tabel 5.

Tabel 5. Ringkasan Data Ketuntasan Individual dan Klasikal yang diperoleh dari Hasil Pre Test dan Post Test Siklus 2

\begin{tabular}{|c|c|c|c|c|c|}
\hline Sumber & Skor & \multicolumn{2}{|c|}{ Hasil Belajar } & \multirow{2}{*}{ Tuntas } \\
Data & Maksimum & Tuntas (org) & Tidak tuntas (org) & Jumlah & Klasikal \\
\hline Pre test & 100 & 10 & 22 & 32 & $31,25 \%$ \\
Post test & 100 & 29 & 3 & 32 & $90,63 \%$ \\
\hline
\end{tabular}

Pada Tabel 5, persentase siswa yang tuntas pada pre test sebesar 31,25\%. Hal ini menunjukkan kemampuan awal siswa masih rendah dan belum mencapai ketuntasan klasikal. Pada post test, persentase siswa yang tuntas sebesar 90,63\%. Hal ini menunjukkan bahwa ketuntasan klasikal telah mencapai batas yang ditetapkan yaitu sebesar $\geq 85 \%$. Peningkatan hasil belajar dari pre test ke post test sebesar 59,38\%. Hal ini berarti penggunaan model pembelajaran dapat meningkatkan hasil belajar siswa pada siklus 2 . 


\section{Aktivitas siswa dalam pembelajaran siklus 2}

Aktivitas siswa dalam pembelajaran pada siklus 2 seperti, sedangkan ringkasannya seperti pada Tabel 6. Pada siklus 2, dalam tabel parameter pengamatan bahwa aktivitas siswa tetap terlihat aktif karena terdapat $\geq 2$ siswa yang menunjukkan nilai $\geq 10 \%$, dan terdapat pada 7 parameter dari 9 parameter yang diamati yaitu pada parameter $1,2,4,5,6,8$, dan 9 .

\section{Tabel 6. Aktivitas Siswa dalam Pembelajaran pada Siklus 2}

Kategori Aktivitas Siswa $<10 \%$ rendah (buruk), $\geq 10 \%$ tinggi (baik); $(\mathrm{T}=$ Tinggi dan $\mathrm{R}=$ Rendah)

\begin{tabular}{|c|c|c|c|c|c|c|c|c|c|c|c|}
\hline \multirow[t]{2}{*}{ Responden } & & \multicolumn{9}{|c|}{ Parameter Yang Dinilai } & \multirow[t]{2}{*}{ Jumlah } \\
\hline & & 1 & 2 & 3 & 4 & 5 & 6 & 7 & 8 & 9 & \\
\hline \multirow[t]{2}{*}{ Eko.K.S } & $\mathrm{F}$ & 5 & 7 & 3 & 5 & 5 & 4 & 3 & 4 & 4 & 40 \\
\hline & $\%$ & 12,5 & 17,5 & 7,5 & 12,5 & 12,5 & 10 & 7,5 & 10 & 10 & 100 \\
\hline \multirow[t]{2}{*}{ M.Fadil. S } & $\mathrm{F}$ & 5 & 6 & 3 & 4 & 5 & 5 & 3 & 5 & 4 & 40 \\
\hline & $\%$ & 12,5 & 15 & 7,5 & 10 & 12,5 & 12,5 & 7,5 & 12,5 & 10 & 100 \\
\hline \multirow[t]{2}{*}{ Nur. M } & $\mathrm{F}$ & 5 & 7 & 3 & 4 & 5 & 4 & 3 & 5 & 4 & 40 \\
\hline & $\%$ & 12,5 & 17,5 & 7,5 & 10 & 12,5 & 10 & 7,5 & 12,5 & 10 & 100 \\
\hline \multirow[t]{2}{*}{ Nurul. A } & $\mathrm{F}$ & 6 & 5 & 3 & 4 & 6 & 5 & 3 & 4 & 4 & 40 \\
\hline & $\%$ & 15 & 12,5 & 7,5 & 10 & 15 & 12,5 & 7,5 & 10 & 10 & 100 \\
\hline \multirow[t]{2}{*}{ Rata-Rata } & $\mathrm{F}$ & 5,3 & 6,3 & 3 & 4,3 & 5,3 & 4,5 & 3 & 4,5 & 4 & 40 \\
\hline & $\%$ & 13,3 & 15,8 & 7,5 & 10,8 & 13,3 & 11,3 & 7,5 & 11,3 & 10 & 100 \\
\hline
\end{tabular}

\section{Keterangan parameter:}

1. Memperhatikan penjelasan guru atau siswa lain.

2. Membaca LKS, buku siswa

3. Melakukan pengamatan/percobaan

4. Menulis hal-hal yang releven dengan KBM.

5. Berdiskusi antar siswa/ kelompok/ guru

6. Merefleksi dan mengevaluasi proses penyelidikan

7. Bertanya kepada siswa lain atau kepada guru.

8. menyusun/melaporkan dan menyajikan hasil penyelidikan.

9. Membuat/menulis rangkuman pelajaran

Pembelajaran pada siklus 2 ini dapat dikatakan lebih baik daripada pembelajaran pada siklus 1 karena aktivitas siswa lebih merata pada semua parameter pengamatan yang berarti ada kerjasama yang baik dalam kelompok sehingga siswa yang aktif dapat membantu siswa yang lain untuk melakukan aktivitas pada parameter yang diamati.

Parameter 3 yaitu melakukan pengamatan atau percobaan otot dan persendian. Hal ini terjadi dikarenakan kesalahan persepsi dari peneliti dan juga pengamat saat penelitian dilakukan yang mana parameter 3 yaitu melakukan pengamatan atau percobaan itu bisa diartikan sebagai suatu tindakan responden untuk mengamati zat aditif bahan makanan buatan melalui gambar (media untuk memahami konsep) tidak hanya melakukan pengamatan pada saat praktikum saja. Untuk parameter 7, yang masih kurang dari $10 \%$ memang merupakan tantangan karena bertanya kepada siswa lain atau kepada guru. Pada kegiatan pembelajaran siklus 2 ini aktivitas siswa dapat dikatakan baik. Selain melihat aktivitas yang dilakukan oleh siswa selama proses pembelajaran, perlu juga memperhatikan keterlaksanaan dalam pembelajaran yang dilakukan oleh guru.

\section{Keterlaksanaan guru dalam pembelajaran pada siklus 2}


Data keterlaksanaan guru dalam pembelajaran siklus 2 disajikan pada Tabel 7 berikut.

Tabel 7. Ringkasan Data Keterlaksanaan Pembelajaran pada Siklus 2

\begin{tabular}{|l|c|}
\hline \multirow{2}{*}{ Tahapan } & Siklus 2 \\
\cline { 2 - 2 } & Pertemuan 1 \\
\hline A. Tahap 1. Kegiatan awal & 3,83 \\
\hline B. Tahap 2. Kegiatan inti & 4,00 \\
\hline C. Tahap 3. Kegiatan akhir & 4,00 \\
\hline Rata-rata & 3,94 \\
\hline Kategori & Baik \\
\hline
\end{tabular}

Keterangan 1 = Kurang baik, $2=$ Cukup baik, 3 = Baik, $4=$ Sangat baik

Berdasarkan Tabel 6 untuk keterlaksanaan pembelajaran yang dilakukan guru pada siklus 2 untuk tahapan kegiatan awal, tahapan kegiatan inti dan penutup sudah termasuk dalam kategori baik, dan begitu juga dengan skor rata-rata 3,94.

8. Respon siswa terhadap pembelajaran dengan Model Kooperatif Type Student Teams Achievement Divisions ( STAD ) pada Siklus 1

Data hasil respon siswa setelah selesai proses belajar mengajar pada pembelajaran siklus 1 ringkasannya seperti pada Tabel 8 .

Tabel 8. Respon Siswa terhadap Pembelajaran dengan Model Kooperatif Type Type Student Teams Achievement Divisions ( STAD ) siklus 1

\begin{tabular}{|c|c|c|}
\hline Uraian & Senang & Tidak Senang \\
\hline $\begin{array}{l}\text { i. Bagaimana pendapatmu terhadap komponen } \\
\text { 1.Topik IPA yang dipelajari } \\
\text { 2.LKS } \\
\text { 3.Buku Siswa } \\
\text { 4.Suasana kelas } \\
\text { 5.Penampilan Guru } \\
\text { 6.Strategi Belajar yang dilatihkan guru (ceramah, } \\
\text { diskusi, pengamatan dan tanya jawab) }\end{array}$ & $\begin{array}{l}93,75 \% \\
96,87 \% \\
90,63 \% \\
90,63 \% \\
93,75 \%\end{array}$ & $\begin{array}{l}6,25 \% \\
3,13 \% \\
9,37 \% \\
9,37 \% \\
6,25 \%\end{array}$ \\
\hline \multirow[b]{2}{*}{$\begin{array}{l}11 \text { Apakah kamu berminat untuk mengikuti Kegiatan } \\
\text { Belajar Mengajar berikutnya seperti yang telah } \\
\text { kamu ikuti. }\end{array}$} & $\mathrm{Ya}$ & Tidak \\
\hline & $93,75 \%$ & $6,25 \%$ \\
\hline \multirow{2}{*}{$\begin{array}{l}\text { 111. Berikan komentarmu terhadap buku siswa } \\
\text { Mengenai: } \\
\text { a. Bahasanya mudah dimengerti } \\
\text { b. Penampilan buku menarik } \\
\text { c. Isi buku menarik }\end{array}$} & Ya & Tidak \\
\hline & $\begin{array}{c}96,87 \% \\
100 \% \\
100 \%\end{array}$ & $\begin{array}{l}3,13 \% \\
0 \% \\
0 \%\end{array}$ \\
\hline
\end{tabular}

Tabel 8. menunjukkan bahwa siswa menyatakan terhadap komponen kegiatan belajar mengajar senang 93,75\% dan tidak senang 6,25\%. Berminat mengikuti KBM berikutnya menyatakan ya $93,75 \%$ dan tidak $6,25 \%$, memberi komentar terhadap buku siswa ya $98,9 \%$ dan tidak $1,1 \%$.

Evaluasi terhadap proses pembelajaran pada siklus 2 dapat diuraikan sebagai berikut:

1. Siswa telah mencapai ketuntasan klasikal sebesar $88,57 \%$, ketuntasan ini telah melewati batas ketuntasan klasikal yang ditetapkan sebesar $\geq 85 \%$. 
2. Aktivitas siswa meningkat, semua parameter telah dilakukan oleh siswa dan aktivitasnya sudah terdistribusi lebih merata pada semua parameter pengamatan apabila dibandingkan pada proses pembelajaran pada siklus 1 .

3. Guru melaksanakan pembelajaran baik pada siklus 1 dan siklus 2 sudah baik.

4. Respon siswa pada siklus 1 dan siklus 2 sudah baik.

\section{Deskripsi Hasil Selama Pembelajaran Siklus 1 dan Siklus 2}

Hasil-hasil penelitian di atas dapat dimaknai lebih lanjut dengan cara membandingkan kedua hasil yang diperoleh pada siklus 1 dan siklus 2 .

10. Hasil belajar siswa berupa pre test dan post test pada siklus 1 dan siklus 2

Hasil belajar berupa pre tes dan post tes pada siklus 1 dan siklus 2 seperti pada Tabel 1 dan Tabel 5 sedangkan ringkasannya seperti pada Tabel 9.

Tabel 9. Ketuntasan Belajar pada Siklus 1 dan Siklus 2

\begin{tabular}{|c|c|c|c|c|c|}
\hline \multirow{2}{*}{ Siklus } & \multirow{2}{*}{ Test } & \multicolumn{2}{|c|}{ Hasil belajar } & \multirow{2}{*}{ Jumlah } & $\%$ \\
\cline { 3 - 4 } & & Tuntas (Org) & Tidak Tuntas (Org) & & Tuntas \\
\hline \multirow{2}{*}{1} & Pre tes & 7 & 25 & 32 & 21,87 \\
& Post tes & 22 & 10 & 32 & 68,75 \\
\hline \multirow{2}{*}{2} & Pre tes & 10 & 22 & 32 & 31,25 \\
& Post tes & 29 & 3 & 32 & 90,63 \\
\hline
\end{tabular}

Tabel 12 menunjukkan hasil ketuntasan klasikal yang diperoleh dari hasil pre test pada siklus 1 maupun siklus 2 belum mencapai ketuntasan klasikal yang ditetapkan karena nilai ketuntasan klasikalnya hanya sebesar 21,87\% dan 31,25\%. Sedangkan ketuntasan klasikal yang diperoleh dari hasil post test pada siklus 1 juga belum mencapai ketuntasan klasikal karena nilai ketuntasan klasikalnya hanya sebesar $68,75 \%$, sedangkan pada siklus 2 sudah mencapai ketuntasan klasikal yang ditetapkan ( $\geq 85 \%)$ karena ketuntasannya sebesar 90,63\%.

\section{Aktivitas Siswa dalam Proses Pembelajaran siklus 1 dan Siklus 2}

Aktivitas siswa dalam pembelajaran siklus 1 dan siklus 2 diperlihatkan seperti pada Tabel 2 dan Tabel 6 sedangkan ringkasannya seperti pada Tabel 10.Tabel 10 memperlihatkan aktivitas siswa pada pembelajaran siklus 1 dan siklus 2, dari 9 parameter pengamatan terhadap aktivitas siswa ada yang mengalami peningkatan dan ada yang mengalami penurunan.

Tabel 10. Aktivitas Siswa dalam Pembelajaran Siklus 1 dan Siklus 2 Kategori Aktivitas Siswa $<10 \%$ rendah (buruk), $\geq 10 \%$ tinggi (baik)

\begin{tabular}{|l|l|l|l|l|l|l|l|l|l|l|}
\hline \multirow{2}{*}{$\begin{array}{l}\text { Siswa yang } \\
\text { diamati }\end{array}$} & \multirow{2}{*}{ Siklus } & \multicolumn{8}{|c|}{ Parameter yang diamati } \\
\cline { 3 - 11 } & & 1 & 2 & 3 & 4 & 5 & 6 & 7 & 8 & 9 \\
\hline \multirow{2}{*}{ Eko.K.S } & 1 & 15 & 12,5 & 10 & 7,5 & 15 & 7,5 & 10 & 15 & 7,5 \\
\cline { 2 - 11 } & 2 & 12,5 & 17,5 & 7,5 & 12,5 & 12,5 & 10 & 7,5 & 10 & 10 \\
\hline \multirow{2}{*}{ M.Fadil.S } & 1 & 15 & 12,5 & 10 & 7,5 & 15 & 7,5 & 10 & 12,5 & 7,5 \\
\cline { 2 - 11 } & 2 & 12,5 & 15 & 7,5 & 10 & 12,5 & 12,5 & 7,5 & 12,5 & 10 \\
\hline \multirow{2}{*}{ Nur. R } & 1 & 12,5 & 15 & 12,5 & 7,5 & 12,5 & 7,5 & 12,5 & 15 & 5 \\
\cline { 2 - 11 } & 2 & 12,5 & 17,5 & 7,5 & 10 & 12,5 & 10 & 7,5 & 12,5 & 10 \\
\hline \multirow{2}{*}{ Nurul. A } & 1 & 20 & 7,5 & 15 & 7,5 & 10 & 7,5 & 10 & 15 & 7,5 \\
\cline { 2 - 10 } & 2 & 15 & 12,5 & 7,5 & 10 & 15 & 12,5 & 7,5 & 10 & 10 \\
\hline
\end{tabular}

Keterangan parameter:

1. Memperhatikan penjelasan guru atau siswa lain.

2. Membaca LKS atau buku-buku yang relevan.

3. Melakukan pengamatan/percobaan 
4. Menulis hal-hal yang relevan dengan KBM.

5. Berdiskusi antar siswa/ kelompok/ guru

6. Melakukan analisis dan mengevaluasi informasi dari hasil penyelidikan.

7. Bertanya kepada siswa lain atau kepada guru.

8. menyusun/melaporkan dan menyajikan hasil penyelidikan.

9. Membuat/menulis rangkuman pelajaran.

Pada siklus 1 dan 2, aktivitas siswa dapat dikatakan baik karena 5 dari 9 parameter menunjukkan kategori aktivitas siswa $\geq 10 \%$. Pada tabel 6 dapat dilihat bahwa pada siklus 2 aktivitas siswa meningkat dari siklus 1 karena aktivitas sudah siswa lebih merata pada semua parameter pengamatan yang berarti belum ada kerjasama yang baik dalam kelompok akan tetapi pada parameter 3pada zat aditif pada bahan makanan buatan. Hal ini terjadi dikarenakan terjadinya kesalahan persepsi dari peneliti dan juga pengamat pada saat penelitian dilakukan yang mana parameter 3 yaitu melakukan pengamatan atau percobaan itu bisa di artikan sebagai suatu tindakan dari responden untuk mengamati gambar (media untuk memahami konsep) tidak hanya melakukan pengamatan pada saat praktikum saja.

Untuk parameter 7 , yang masih kurang dari $10 \%$ memang merupakan tantangan karena bertanya kepada siswa lain atau kepada guru.

\section{Keterlaksanaan Guru dalam Pembelajaran Siklus 1 dan Siklus 2}

Data keterlaksanaan guru dalam pembelajaran siklus 11.

Tabel 11. Ringkasan Data Keterlaksanaan Guru dalamPembelajaran pada Siklus 1 dan Siklus 2

\begin{tabular}{|l|c|c|}
\hline \multicolumn{1}{|c|}{ Tahapan } & Siklus 1 & Siklus 2 \\
\hline A. Tahap 1. Kegiatan awal & 3,83 & 3,83 \\
\hline B. Tahap 2. Kegiatan inti & 3,50 & 4,00 \\
\hline C. Tahap 3. Kegiatan akhir & 4,00 & 4,00 \\
\hline Rata-rata & 3,78 & 3,94 \\
\hline Kategori & Baik & Baik \\
\hline
\end{tabular}

Keterangan 1 = Kurang baik, $2=$ Cukup baik, 3 = Baik, $4=$ Sangat baik

Berdasarkan Tabel 11. untuk keterlaksanaan pembelajaran yang dilakukan guru pada siklus 1 maupun siklus 2 untuk tahapan kegiatan awal, tahapan kegiatan inti dan penutup sudah termasuk dalam kategori baik.

\section{Respon Siswa terhadap Pembelajaran Model Kooperatif Type Numbered Head Together (NHT) pada Siklus 1 dan 2}

Tabel 12. Ringkasan Data Respon Siswa dalam Pembelajaran Siklus 1 dan 2

\begin{tabular}{|l|c|c|c|c|}
\hline \multirow{2}{*}{ No } & \multicolumn{2}{|c|}{ Siklus 1 } & \multicolumn{2}{c|}{ Siklus 2 } \\
\cline { 2 - 5 } & Senang & Tdk senang & Senang & Tdk senang \\
\hline a. Bagaimana pendapatmu & & & & \\
$\quad$ terhadap komponen & & & & \\
1.Topik IPA yang dipelajari & $93,75 \%$ & $6,25 \%$ & $93,75 \%$ & $6,25 \%$ \\
2.LKS & $96,87 \%$ & $3,13 \%$ & $96,87 \%$ & $3,13 \%$ \\
3.Buku Siswa & $93,75 \%$ & $6,25 \%$ & $90,63 \%$ & $9,37 \%$ \\
4.Suasana kelas & $75 \%$ & $25 \%$ & $90,63 \%$ & $9,37 \%$ \\
5.Penampilan Guru & $90,63 \%$ & $6,25 \%$ & $93,75 \%$ & $6,25 \%$ \\
6.Strategi Belajar yang dilatihkan & $87,5 \%$ & $12,5 \%$ & $96,87 \%$ & $3,13 \%$ \\
guru (ceramah, diskusi, & & & & \\
pengamatan dan tanya jawab) & & & & \\
\hline
\end{tabular}



Kelas VIII E SMP Negeri 4 Banjarmasin

\begin{tabular}{|l|c|c|c|c|}
\hline 11 Apakah kamu berminat untuk \\
mengikuti Kegiatan Belajar \\
$\begin{array}{l}\text { Mengajar berikutnya seperti } \\
\text { Yang telah kamu ikuti. }\end{array}$ & $90,63 \%$ & $12,5 \%$ & $93,75 \%$ & $6,25 \%$ \\
\hline $\begin{array}{l}\text { 111. Berikan komentarmu terhadap } \\
\text { buku siswa mengenai: }\end{array}$ & $96,87 \%$ & $3,13 \%$ & $96,87 \%$ & $3,13 \%$ \\
a. Bahasanya mudah dimengerti & $93,75 \%$ & $6,25 \%$ & $100 \%$ & $0 \%$ \\
b. Penampilan buku menarik & $87,5 \%$ & $12,5 \%$ & $100 \%$ & $0 \%$ \\
c. Isi buku menarik & & & & \\
\hline
\end{tabular}

\section{B. Pembahasan}

Pembahasan hasil penelitian pembelajaran dengan menggunakan Model Kooperatif Type Student Teams Achievement Divisions ( STAD ) berdasarkan data kualitatif berupa hasil belajar dan data kuantitatif berupa pengamatam aktivitas siswa, keterlaksanaan guru dan respon siswa dari hasil angket siswa dalam pembelajaran ditujukan untuk menjawab tujuan penelitian seperti yang telah dirumuskan pada bagian terdahulu.

\section{Hasil belajar}

Hasil belajar produk merupakan jawaban dari tujuan penelitian yang pertama yaitu meningkatkan hasil belajar siswa. Hasil penelitian pembelajaran dengan menggunakan Model Kooperatif Type Student Teams Achievement Divisions ( STAD ) dapat meningkatkan hasil belajar produk dan peningkatan ini berpengaruh secara signifikan.Temuan ini sejalan dengan penelitian yang telah dilaporkan sebelumnya bahwa pembelajaran menggunakan Model Kooperatif Type Student Teams Achievement Divisions ( STAD ) dapat meningkatkan hasil belajar siswa ( Dedi Heriyadi, 2016 ).

Berdasarkan Tabel 1, pada siklus 1 terjadi peningkatan hasil belajar dari pre test ke post test dimana persentase siswa yang tuntas pada pre test hanya sebesar $0 \%$ dan persentase siswa yang tuntas pada post test meningkat menjadi $68,75 \%$. Hal ini menunjukkan bahwa ketuntasan klasikal belum mencapai batas yang ditetapkan yaitu sebesar $\geq 85 \%$. Peningkatan hasil belajar dari pre test ke post test sebesar $68,75 \%$. Hal ini berarti penggunaan Model Kooperatif Type Student Teams Achievement Divisions (STAD) dapat meningkatkan hasil belajar siswa pada siklus 1 akan tetapi masih belum mencapai batas yang ditetapkan yaitu sebesar $\geq 85 \%$.

Berdasarkan Tabel 5 pada siklus 2 terjadi peningkatan hasil belajar dari pre test ke post test. Persentase siswa yang tuntas pada pre test sebesar $0 \%$. Hal ini menunjukkan kemampuan awal siswa masih rendah dan belum mencapai ketuntasan klasikal. Pada post test, persentase siswa yang tuntas sebesar 90,63\%. Hal ini menunjukkan bahwa ketuntasan klasikal telah mencapai batas yang ditetapkan yaitu sebesar $\geq 85 \%$. Peningkatan hasil belajar dari pre test ke post test sebesar 90,63\%. Hal ini berarti penggunaan Model Kooperatif Type Student Teams Achievement Divisions (STAD) dapat meningkatkan hasil belajar siswa pada siklus 2 .

\section{Aktivitas siswa dalam pembelajaran}

Berdasarkan Tabel 2, aktivitas siswa pada siklus 1 dari 9 parameter yang teramati terdapat 3 parameter yang menunjukkan keaktifan siswa yang masih kurang yaitu pada parameter 4, 6, dan 9. Sedangkan pada parameter yang 
menunjukkan keaktifan siswa tertinggi yaitu pada parameter $.1,2,3,5,7$, dan 8, dengan aktivitas memperhatikan penjelasan guru atau siswa lain, membaca LKS atau buku-buku yang relevan, melakukan pengamatan/percobaan, berdiskusi antar siswa/ kelompok/ guru, bertanya kepada siswa lain atau guru dan menyusun/menyajikan hasil penyelidikan. Pada kegiatan pembelajaran siklus 1 ini siswa sudah terlihat ikut berpartisipasi aktif dalam proses pembelajaran, karena terdapat 5 dari 9 parameter menunjukkan nilai $\geq 10 \%$ dikatakan baik apabila siswa dapat ikut serta secara aktif dalam pembelajaran (aktivitas siswa tinggi). Aktivitas siswa dikatakan baik apabila nilai persentase kategori aktivitas siswa $\geq$ $10 \%$ (tinggi) dan dikatakan buruk jika $<10 \%$ (rendah). Jumlah siswa yang diamati sebanyak 4 orang siswa dalam 1 kelompok, jika terdapat 2 orang siswa atau lebih yang memiliki tingkat keaktifan $\geq 10 \%$ maka dapat dikatakan bahwa keaktifan siswa pada parameter yang diamati tersebut tinggi. Selain itu apabila pada 9 kategori parameter aktivitas siswa yang diamati terdapat lebih dari atau sama dengan 5 parameter yang nilainya tinggi maka dapat dikatakan bahwa aktivitas siswa pada pembelajaran yang berlangsung baik (siswa aktif). Pada kegiatan pembelajaran siklus 1 ini aktivitas siswa dapat dikatakan baik karena terdapat 5 parameter dari 9 parameter yang diamati memiliki nilai $\geq 10 \%$.

Berdasarkan Tabel 6, pada siklus 2 aktivitas siswa tetap terlihat aktif karena terdapat $\geq 2$ orang siswa yang menunjukkan nilai $\geq 10 \%$ pada parameter yang menunjukkan peningkatan dan terdapat 7 parameter dari 9 parameter yang diamati juga menunjukkan nilai $\geq 10 \%$. Selain itu, aktivitas siswa lebih merata pada semua parameter pengamatan. Hal ini menunjukkan bahwa aktivitas siswa dalam pembelajaran dengan menggunakan model pembelajaran Type Student Teams Achievement Divisions ( STAD ) pada siklus 2 sudah baik. Hasil ini sejalan dengan temuan yang pernah dilaporkan bahwa aktivitas siswa dalam pembelajaran pada siklus 1 ke siklus 2 mengalami poeningkatan (Al Faizah, 2011; Ella Nulaela, 2015; Sagiyan Taruna,Alip, 2011).

\section{Keterlaksanaan guru dalam pembelajaran}

Berdasarkan Tabel 3. untuk keterlaksanaan pembelajaran yang dilakukan guru pada siklus 1 dengan rata-rata nilai adalah 3,78\% maupun siklus 2 dengan rata-rata nilai 3,94\% untuk tahapan kegiatan awal, tahapan kegiatan inti dan penutup sudah termasuk dalam kategori baik .Melakukan pengamatan melalui demontrasi dan gambar tentang sistem gerak pada manusia dalam pembelajaran yang dilakukan dengan menggunakan Model Kooperatif Type Student Teams Achievement Divisions (STAD) ini, diharapkan siswa mampu melakukan pengamatan secara langsung maupun tak langsung bahkan percobaan dengan menggunakan sistem gerak pada manusia yang sudah sering mereka lihat untuk memperoleh pengetahuan sesuai materi yang akan diajarkan oleh guru. Hal ini merupakan pengalaman belajar yang baru bagi siswa, sehingga memberikan nuansa yang baru juga bagi siswa dan dikarenakan komponen pembelajaran yang digunakan dapat membantu siswa dan guru dalam melaksanakan kegiatan pembelajaran. Hal ini sejalan dengan hasil-hasil penelitian sebelumnya dengan menggunakan Model Kooperatif Type Student Teams Achievement Divisions (STAD) bahwa respon guru yang positif terhadap proses pembelajaran ( Juli Setyanto, 2011; Antin Triyana, 2010). 


\section{Respon siswa setelah selesai dalam pembelajaran}

Berdasarkan respon siswa pada pembelajaran pada pembelajaran siklus 1 senang 90,63\% , tidak senang 9,38\%, berminat mengikuti KBM berikutnya 90,63\%, tidak berminat mengikuti KBM berikutnta 9,37\% , memberi komentar terhadap buku siswa $92,71 \%$ dan yang tidak memberi komentar terhadap buku siswa 7,29\%, dan siklus 2 senang 93,75\% dan tidak senang 6,25\%, berminat mengikuti KBM berikutnya $93,75 \%$ dan tidak berminat mengikuti KBM berikutnya $6,25 \%$, memberi komentar terhadap buku siswa 98,96\% dan tidak memberikan komentar terhadap buku siswa $1,04 \%$ ada peningkatan pada penggunaan Model Kooperatif Type Student Teams Achievement Divisions (STAD) baik pada siklus 1 dan siklus 2 .

Berdasarkan angket tersebut maka siswa melakukan kegiatan pengamatan dengan menggunakan gambar dan demonstrasi mendapatkan respon siswa. Hal ini menandakan bahwa siswa telah menngunakan kesempatan memperoleh pengalaman . Menurut Yulaewati, (2004) keberhasilan dalam pembelajaran belum cukup dengan membaca, mendengar saja, namun pembelajaran akan lebih bermakna siswa dapat membaca, mendengar dan melihat. Melalui kegiatan belajar tersebut memotivasi untuk mencari tahu jawabannya. Arends, (2001) mengemukakan pembelajaran yang berpusat pada siswa atau student-centered instruction, menekankan pada hakekatnya sosial dari belajar dan menekankan scaffolding sehingga siswa membangun pengetahuan dibenaknya sendiri. LKS merupakan paduan bagi siswa untuk melakukan kegiatan penyelidikan dan pengamatan.

\section{A. Kesimpulan}

\section{KESIMPULAN DAN SARAN}

Berdasarkan pembahasan di atas maka dapat ditarik beberapa kesimpulan sebagai berikut:

1. Penerapan Model Kooperatif tipe STAD dengan konsep sistem gerak manusia berpengaruh nyata pada hasil belajar baik pembelajaran siklus 1 maupun pembelajaran siklus 2 .

2. Berdasarkan data kualitatif, pembelajaran telah berpusat kepada siswa meskipun belum optimal. Aktivitas siswa sudah menunjukkan peningkatan dan tergolong kategori baik dari siklus 1 maupun siklus 2.Dari 9 parameter aktivitas siswa yang teramati ada 6 parameter menunjukkan adanya peningkatan dan 3 parameter yang menunjukkan adanya penurunan aktivitas siswa.

3. Berdasarkan data kualitatif, keterlaksanaan guru dalam pembelajaran sudah baik dalam proses pembelajaran dari siklus 1 ke siklus 2 .

4. Berdasarkan data kualitatif, pembelajaran telah berpusat kepada siswa meskipun belum optimal. Respon siswa sudah menunjukkan peningkatan dan tergolong kategori baik dari siklus 1 maupun siklus 2. Dari 9 parameter respon siswa yang teramati menunjukkan adanya sedikit penurunan respon siswa pada siklus 2 parameter 1 nomer 4 tetapi masih baik dari respon siswa.

\section{B. Saran}

Berdasarkan pembahasan diatas maka ada beberapa saran sebagai berikut:

1. Guru-guru/peneliti yang ingin mencoba model ini perlu persiapan, pengetahuan, kemampuan untuk menggunakannya serta perlu adanya guru pendamping untuk mengarahkan dan mengawasi siswa. 
2. Pemilihan siswa sample sebaiknya menggunakan sekolah dengan grade yang baik di atas rata-rata, karena keberhasilan penerapan model STAD ditentukan oleh kemampuan kelompok bukan perorangan.

\section{DAFTAR PUSTAKA}

Arends.R.I, 1997. Classroom Instructional and Management.Mc. Graw. Hill Book Companies Inc, New York.

Arikunto, Suharsimi, 2008 . Prosedur Penelitian Suatu Pendekatan Praktek.Jakarta: Rineka Cipta.

Andi, Sofyan. 2008. Implementasi CD Animasi Pendidikan Indonesia Untuk Meningkatkan Kualitas Pembelajaran Sains Siswa Kelas V SD Negeri Catur Tunggal04. Program Pascasarjana Universitas Negeri Yogyakarta. Tesis (Tidak dipublikasikan).

Asmaridha, Elvera Listya. 2009. Meningkatkan Hasil Belajar Siswa Kelas VII SMP Negeri 2 Belawang pada Materi Ajar Zat dan Wujudnya DenganMenerapkan pembelajaran Kooperatif Tipe STAD. Program studi Pendidikan Biologi, Unlam, Banjarmain. (Tidak diterbitkan )

Borich,G.D. 2005. Observation Skill For Effective Teaching, New York : MacmillanPublishing Company.

Cocta, A. L. 1985. Developing Minds A Resourse Book for Teaching Thinking.Virginia: Association for Supervision and Curriculum Development.

Champbell, Donald T \& Julian, Stanley, 1996. Experimental and Quasi Experimental Design for Research On Teaching. Dalam N.L. Gage (penyuting).Handbook Of Reseaech On Teaching. A Project of American Education Research . Association. Departemen of The National Education Association. Chicago.

Depdiknas. 2007. Peseraturan Menteri Pendidikan Nasional No 41 Tahun 2007 Tentang Standar Isi.Depdiknas : Jakarta.

Depdiknas. 2006. Peraturan Menteri Pendidikan Nasional No.22 Tahun 2006 Tentang Standar Isi. Depdiknas : Jakarta.

Ennis, R. 1996. Ctical Thinking, New Jesy : Simon \&Schuster/ A Viacom Company.

Dimyati dan Mudjiono, 1999. Belajar dan Pembelajaran. Rineka Cipta. Jakarta.

Douglas Fister \& Nancy Rrey. 2007. Checking for Understanding : Formative Assessment Techniques for your Classroom. Association for Supervision \& Corriculum Developarent. USA.

Furoidah, 2009. Pengaruh Penggunaan Media Animasi Pembelajaran Terhadap Hasil Belajar Siswa Mata Pelajaran Biologi Kelas VIII MTS Surya Buana Malang. Universitas Negeri Malang (Tidak dipublikasikan).

Furchan, A. 2007. Pengantar Penelitian Dalam Pendidikan. Yogyakarta : Pustaka Pelajar

Gronlund, N.E. 1982. Constructing Achievement Test. Englewood Cliffs, N J: PrenticeHall 
Hasil Belajar Melalui Penerapan Model Pembelajaran Kooperatif Type Student Teams Achievement Division (STAD) Konsep Sistem Gerak pada Manusia di Kelas VIII E SMP Negeri 4 Banjarmasin

Jusuf, Elly,Arifiati. 2000. Pengembangan Perangkat Pembelajaran Biologi SLTP Pokok Bahasan keanekaragaman Hewan Berorientasi Model Pembelajaran Kooperatif Tipe STAD. Tesis. Program Studi Pendidikan Sains. Program Pascasarjana Unesa; Surabaya. ( Tidak diterbitkan )

Ingraham, Karthryn P, Luginbuhl, Regina C, Schlotzhaur, Sandra D, Watts, Harriet, (Tanpa tahun). SAS/STAT User's Guide Release 6. 03. Cary, North Carolina:SAS Institute Inc.

Isjoni. 2010. Cooperative Learning .Bandung : Affabeta.

Khairunnisa. 2007. Meningkatkan pemahaman Siswa kelas IV SDN Batu Piring Paringin Balangan pada Konsep Daur Hidup Hewan Dengan Menggunakan Pendekatan Kooperatif Tipe STAD Melalui Medicine Wheel, Program Studi Pendidikan Biologi. Unlam : Banjarmasin (Tidak diterbitkan).

Karim, s, dkk.Belajar IPA Membuka Cakrawala Alam Sekitar untuk kelas VIII SMP. Jakarta : Setia Purna Invers.

Liliawati,W \& Samsudin,A. 2011. Efektivitas Pembelajaran Fisika Dengan Menggunakan Media Animasi Komputer Terhadap Peningkatan Keterampilan Berpikir Kritis Siswa SMA. Universitas Negeri Yogyakarta. Proseding Seminar Nasional.

Nur, M dan Wikandari P.R. 2000. Pengajaran Berpusat Pada Siswa dan Pendekatan Konstruktivisme. Surabaya: Universitas Negeri Surabaya University Press.

Nur, M. 2011. Model Pembelajaran Kooperatif. Surabaya : Pusat Sains dan Matematika Sekolah. Unesa. ( tidak diterbitkan ).

Nurgiyanto, Heru. 2011. Penerapan Pembelajaran Siklus BelajarBerbantuan Media Animasi Komputer Untuk Meningkatkan Keterampilan Kerja Ilmiah dan Hasil Belajar IPA Siswa Kelas VIII-H SMP Negeri 4 Kepanjen Kabupaten Malang. Tesis. Program Pascasarjana Universitas Negeri Malang (Tidak dipublikasikan).

Norrahmi, Siti. 2008. Meningkatkan Pemahaman Pada Konsep Penyesuaian MakhlukHidup Dengan Lingkungannya Melalui Model pembelajaran Kooperatif Tipe STAD. Skripsi. Program Studi Pendidikan Biologi. Unlam; Banjarmasin (Tidak diterbitkan).

Puryangsih,S. 2008. Penggunaan Media Animasi Ditinjau dari Motivasi Berprestasi dan Kemampuan Awal dalam Pembelajaran Biologi Umum. Tesis Program Pascasarjana UNS: Surakarta (Tidak dipublikasikan).

Usman, M, 1995, Menjadi Guru Profesional.bandung : Remaja Rosdikarya.

Richard L. Arends. 2008. Learning to Teach.Edisi ke 7. Yogyakarta :

Pustaka Pelajar.

Rusman. 2010. Model-model Pembelajaran mengembangkan Profesional .

Guru, Jakarta : Rajawali Press.

Revsy. 2011. Pengaruh Penggunaan Media Torso Animasi Terhadap Peningkatan Hasil Belajar Siswa Pada Mata Pelajaran IPA. (Penelitian Kuasi Eksperimen di Kelas V Sekolah Dasar Negeri Mekarsari 06 
Tambun Selatan). Universitas Pendidikan Indonesia (Tidak dipublikasikan).

Riwayati. 2010. Meningkatkan Motivasi dan Prestasi Belajar Siswa Kelas VIII SMPN 2 Pare melalui Pembelajaran Berbantuan Macromedia Flash 8, Tesis. Pascasarjana Universitas Negeri Malang (Tidak diterbitkan).

Sillberman,M. 1999, Active Learning 101 Strategi pembelajaran Aktif, Yogyakarta: Pustaka Insan Madani.

Sanjaya, Wina, 2009, Strategi Pembelajaran Berorientasi Standar proses Pendidikan, Kencana,Jakarta.

Syamsuri, Istamar. 2007. IPA Biologi Untuk SMP Kelas V111. Malang : Erlangga.

Suryati, 1998. Penerapan Pembelajaran Kooperatif dalam Rangka

Meningkatkan Mutu Hasil Belajar Fisika Siswa. Makalh Komprehensif. Surabaya: Pascasarjana IKIP Surabaya.

Slavin. R. 2008. Cooperative Learning Theory.Second Edition. Massachusetts : Allyn and Bacon Publisher.

Slameto. 2010. Belajar dan Faktor-Faktor Yang Mempengaruhinya.Jakarta: Rineka Cipta.

Suherman, Medriati,G,R. Hubungan Penggunaan dan Motivasi Belajar Terhadap Hasil BelajarKimia Kelas XI IPA Madrasah Aliyah Negeri 2 Kota Bengkulu. Pascasarjana Universitas Bengkulu. Tesis (Tidak dipublikasikan).

Tim Abdi Guru. 2007. IPA Terpadu Untuk SMP Kelas VIII.Jakarta : Erlangga.

Trianto. 2009. Mendesain Model Pembelajaran Inovatif Progresif, Konsep, Landasan dan implementasinya pada Kurikulum Tingkat Satuan Pendidikan (KTSP).Jakarta: Kencana Prenada media Group.

Yulaewati, Ella. 2004. Kurikulum dan Pembelajaran (Filosofi, Teori dan Aplikasi). Pakar Raya. Bandung.

Universitas Negeri Malang. 2000. Pedoman Penulisan Karya Ilmiah.Malang : Universitas Malang.

Utaminingsih, R. 2009. Perbedaan Peningkatan Hasil Belajar Siswa pada Pemanfaatan Media Visual dalam Pembelajaran Sains di SMP Negeri 2 Wanadadi Banjarnegara Tahun 2008/2009.Tesis Program Pascasarjana, Universitas Negeri Yogyakarta (Tidak dipublikasikan).

Zaini, Muhammad dan Warsono. 2005. Memanfaatkan Metode Debat Secara Formal untuk Mengoptimalkan Pemahaman Biotika pada Perkuliahan Genetika Mahasiswa S1 Program Studi Pendidikan Biologi FKIP Unlam Tahun Akedemik 2004/2005. 